\title{
The Effect of Nasal Obstruction on the Susceptibility of Mice to Noxious Gases
}

\author{
Katsuyuki NAKAJIMA, Satoshi TSUCHIYA, \\ Takashi NAKAJIMA and Kenji HARADA \\ Gumma Institute of Public Health \\ 3-21-19 Iwagami-cho Maebashi, Gumma
}

(Received for publication: September 2, 1974)

\begin{abstract}
The effect of nasal obstruction on mice-the maice were forced to breathe through the mouthwas studied when the animals were exposed to noxious gases.

It was noted that the forced mouth breathing made the mice less vulnerable to hydrogen sulfide, carbon monoxide and toluen vapor when expressed by the time interval before they lost righting reflex or showed respiratory arrest. The levels of the gases which could induce these sings within 5-10 minutes were significantly elevated with the "mouth breathing" mice.

Possible mechanisms for this phenomenon and its application for men were discussed.
\end{abstract}

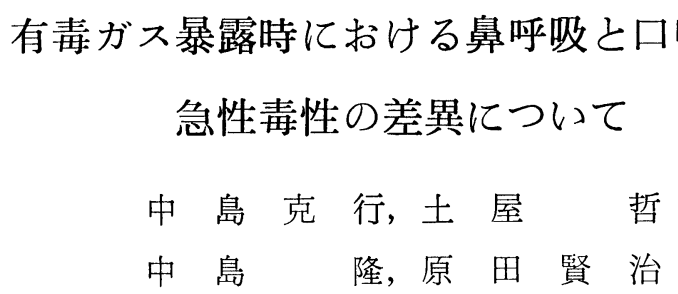

群馬県衛生研究所

昭和46年12月末, 群馬県草津町, 振子沢スキーコース において，高濃度硫化水素に暴露したためと考えられる 6 人のスキーャーの中毒死事故が発生し，乙れを 契 機 に, 著者らは火山性硫化水素の急性毒性について報告し てきた $[1,2,10]$ 。このような事件例は，上述のような自 然発生ガスによる場合のほか, 硫化水素の発生しやすい 工場, その他の事業場における人為発生ガスによる中毒 例もあり, 労㗢衛生の立場加らあ重要な意味を持ってい る。さらに, 最近, いろいろな有毒ガス暴露による事故 (デパート火災, 光化学スモッグ, 有機溶剤暴露, その 他）が各所に発生し，それらに対する防災科学的研究 が，いろいろな角度から進められている。

そこで, 今回は, 生体がこのような有毒ガスに暴露さ れた場合, それから身を守るためどのような調節機能 [7]が存在するか, またどのような手段でその被害を軽 減することが可能であろうかという観点から検討を進め た。

我々が，昨今遭遇する可能性のある有毒ガスは多種に およぶが，それらは多くの場合，肺胞を介して血中に移
行しなければ，生死にかかわる毒性を発揮することはな い。従って, 呼吸を止めていれば安全であるはずである が, 普通の人間の場合, 安静時でも, 止息状態を 1 分以 上維持するのは困難である[9]。これらのととから，有 毒ガス暴露の際には, 有毒ガスの体内とりこみ量を少な くすることが最大の課題であろうと考えられる。

そこで, 呼吸を抑制し, 肺での換気能を低下させる方 法として, 急性鼻閉に着目した。つまり, 鼻閉塞患者の 場合, あるいは，手で鼻をおさえた急性鼻閉により，鼻 肺反射経路が阻害され, 呼吸障害がおき, 呼吸量, 換気 能等が低下することが知られている[15-23，26-31]。 従って, 鼻閉による呼吸障害が, 逆に, 有毒ガス暴露に 対して, 有毒ガスの呼吸器内とりとみ量を制限し, 毒性 発揮を弱める可能性が考えられる。

以上のととから, 鼻閉塞にともなう呼吸障害が確認さ れているロ呼吸マウス[3]を用いて, 硫化水素, 一酸化 炭素, トルエン蒸気に暴露させ, 鼻呼吸ならびに正常呼 吸マウスの場合と比較検討したので報告する。 


\section{材料および方法}

鼻呼吸マウス，口呼吸マウス，鼻孔閉銷一気管呼吸、 ウスを実験的に作成するための手術方法については，す でに報告した[3]。マウスは, dd 系, 雄, 体重 18～22g を用い，暴露実験をおこなったが，手術の際のエーテル 麻酔による影響をとり除くため, マウスは術後 3 時間以 上経過したものを用いた。手術によるストレスの影響を 相殺するため, 口呼吸, 鼻呼吸, 気管呼吸マウス等, 手 術をしてあるマウスをそれぞれ対照として用いた。

ガス暴露による毒性は, 運動能力消失時間と呼吸停止 時間を指標とした。運動能力消失は，正向反射消失と同 じ意味であり, 本実験において, 一度運動能力消失後, 途中で回復するのがみられた（硫化水素暴露の場合）が この実験では, 最初に消失するまでの時間を, 運動能力 消失時間とした。呼吸停止時間についても同様である。

有毒ガスとして用いた硫化水素, 一酸化炭素は, それ ぞれ実験室にて作成し $[4,5]$, 北川式検知管（硫化水素 検知管 $\mathrm{A}$ 型, 一酸化炭素検知管 B型）（光明理化学工業 $\mathrm{KK}$ ），を用いて濃度測定をおてなった。トルエン暴露 については，注入液体トルエン量のすべてが揮発したと してその蒸気濃度とした（実験室温度を $25 \pm 3^{\circ} \mathrm{C}$ に保っ て行う）。暴露実験には， $2 l$ 円筒状透明容器にマウス を入れ，ガス注入後約 5 杪間，ふたにつけてある擋汼機 を回転させ, 容器内のガス濃度が均一になるようにした (写真 1)。濃度の測定は, 実験䊏了時に行い, その暴露 濃度とした (トルエンの場合は注入量)。

本実験にもちいた運動能力消失時間測定は直接観察法 で行ったが, 行動量との関係をむとめるために，著者ら
(23)

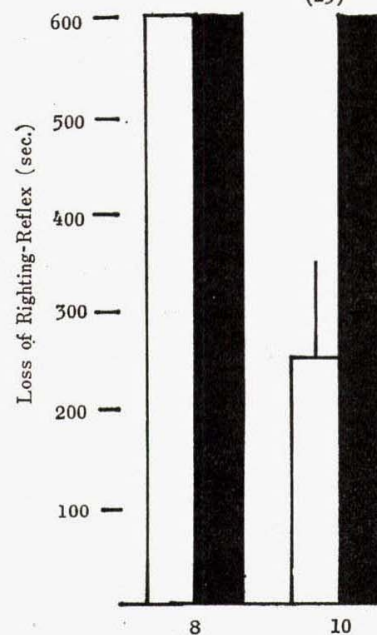

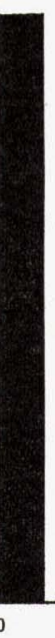

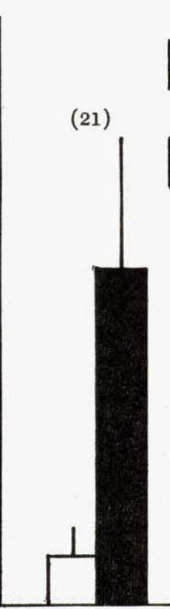

12
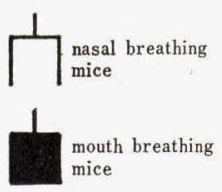

1）硫化水素に鼻呼吸ならびに口呼吸マウスを暴露し た場合の毒性について。

マウスを $1,000 \mathrm{ppm}$ 抢よび1,200ppm の硫化水素に暴 露した場合，それぞれ約 240 秒，30秒で運動能力消失か

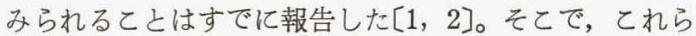
の濃度における, 鼻呼吸マウスと口呼吸マウスの運動能

(17)

600
(23)

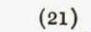

(21)
(21)

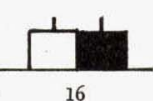

Hybrogen Sulfide Concentration (P.P.M. $\times 10^{2}$ )

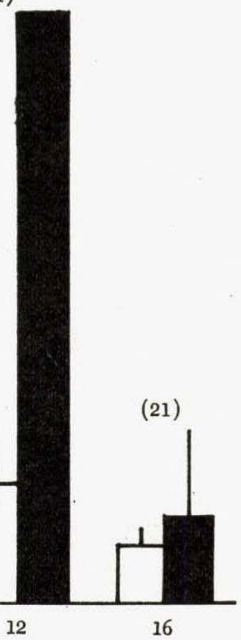

Fig. 1. Time untill the loss of righting reflex (left) and the respiration arrest (right) under exposure to hydrogen sulfide.

In parenthesis are number of mice used. 
力消失時間を比較した所， 口呼吸マウスでは運動能力消 失時間が著明に延長するととが示された(図 1 )。この現 象は，1,400ppm 以上の高濃度の場合においては認めら れなかった。また， 800ppm 以下の低濃度の場合は，運 動能力の消失が10分以内におこらないため，10分以内の 観察では差がなかった。なお, 図 1 から, 鼻呼吸マウス と口呼吸マウスの間で，その急性中毒濃度に約 200ppm の差が認められ, 口呼吸マウスの場合, それだけ毒性発 揮が軽減されるととが示された。

また，鼻孔閉銷の手術方法を，糸で縛るのではなく， ハンダ鏝で鼻孔を焼いて閉じた場合も, 図 1 と全く同じ 結果を得た。乙のてとから，手術そのものによる影響を 否定しうるものと考えられる。

2 ) 同一マウスに扔けるロ呼吸状態と鼻呼吸状態での 硫化水素暴露による毒性の違い。

今回の実験では, 口呼吸マウスと鼻呼吸マウスを常に 同一暴露容器に入れて, 同一濃度下で比較検討した。し 加し，1,000ppm，1，200ppm硫化水素暴露が個体差によ るあのでないととを，より明確にするため，同一マウス におけるロ呼吸状態と鼻呼吸状態の場合について検討し た。実験は $\mathrm{A}-\mathrm{F}$ まで行い, 各 3 匹を同一濃度の硫化水

Table 1. Time untill the loss of righting reflex in mice under exposure to hydrogen sulfide; the effect of exposure in case of nasal or mouth breathing on the same body.

\begin{tabular}{|c|c|c|c|c|}
\hline $\begin{array}{l}\mathrm{H}_{2} \mathrm{~S} \\
\mathrm{ppm}\end{array}$ & $\begin{array}{l}\text { Mouse } \\
\text { Number }\end{array}$ & $\begin{array}{l}\text { Mouth } \\
\text { Breathing } \\
\text { Mice }\end{array}$ & $\begin{array}{l}\text { Nasal } \\
\text { Breathing } \\
\text { Mice }\end{array}$ & $\begin{array}{l}\text { Normal } \\
\text { Breathing } \\
\text { Mice }\end{array}$ \\
\hline 1,100 & $\begin{array}{l}\text { マウス } \mathrm{A}-1 \\
\text { マウス } \mathrm{A}-2 \\
\text { マウス } \mathrm{A}-3\end{array}$ & $\begin{array}{r}(\overline{s e c} .) \\
>600 \\
>600\end{array}$ & $\begin{array}{r}\text { (sec.) } \\
150 \\
20\end{array}$ & $\begin{array}{c}(\mathrm{sec} .) \\
40,30\end{array}$ \\
\hline 1,200 & $\begin{array}{l}\text { マウス B-1 } \\
\text { マウス B-2 } \\
\text { マウス B-3 }\end{array}$ & $\begin{array}{r}120 \\
>480\end{array}$ & $\begin{array}{l}25 \\
20\end{array}$ & 25,20 \\
\hline 1,200 & $\begin{array}{l}\text { マウス C-1 } \\
\text { マウス C-2 } \\
\text { マウス C-3 }\end{array}$ & $\begin{array}{l}210 \\
260\end{array}$ & $\begin{array}{l}25 \\
20\end{array}$ & 35,30 \\
\hline 1,300 & $\begin{array}{l}\text { マウス D-1 } \\
\text { マウス D-2 } \\
\text { マウス D-3 }\end{array}$ & $\begin{array}{r}210 \\
>480\end{array}$ & $\begin{array}{l}25 \\
20\end{array}$ & 20,25 \\
\hline 1,400 & $\begin{array}{l}\text { マウス } \mathrm{E}-1 \\
\text { マウス } \mathrm{E}-2 \\
\text { マウス } \mathrm{E}-3\end{array}$ & $\begin{array}{l}25 \\
20\end{array}$ & $\begin{array}{l}20 \\
25\end{array}$ & 20,20 \\
\hline 1,600 & $\begin{array}{l}\text { マウス F-1 } \\
\text { マウス F-2 } \\
\text { マウス F-3 }\end{array}$ & $\begin{array}{l}20 \\
30\end{array}$ & $\begin{array}{l}25 \\
25\end{array}$ & 25,20 \\
\hline
\end{tabular}

素に 2 回暴露した。つまり,一回目の暴露実験には, 、 ウス $\mathrm{A} \sim \mathrm{F}-1$ を対照とし，マウス $\mathrm{A} \sim \mathrm{F}-2$ を口呼吸 マウス, マウス $\mathrm{A} \sim \mathrm{F}-3$ を鼻呼吸マウスとして, $20 \mathrm{~m} l$ の注射筒に準備した高濃度硫化水素の一定量を暴露箱に 注入し, 運動能力消失時間, 暴露濃度を測定した。二回 目の実験は， 3 日後におこない，マウス $\mathrm{A} \sim \mathrm{F}-1$ を再 び対照として用い，マウス $\mathrm{A} \sim \mathrm{F}-2$ を鼻呼吸マウス， マウス $\mathrm{A} \sim \mathrm{F}-3$ を呼吸マウスとし，前回と同量のガ スに暴露した。その結果, 同一マウスに执いて, 鼻呼吸 状態と口呼吸状態では, 同一濃度暴露による運動能力消 失時間に，図 1 上同様に著明な差が認められた(表 1 )。

3 ）口呼吸マウスにおりる過剩な空気嚥下現象と腹部 膨満の有毒ガス暴露におよぼす影響について。

暴露実験に用いた口呼吸マウスにおいて, 過剩空気嚥 下にともなう腹部膨満現象が認められた[3]が，乙れは， 横隔膜を圧迫し，呼吸機能に影響を与えることが知られ ている。ての腹部膨満の影響を調べるため, あらかじめ 口呼吸状態にし, 過常な空気嬹下のみられるマウスを, 硫化水素暴露実験 5 分前に, 鼻孔を閉じてある系を切断 して正常呼吸に㞍してやり, 腹部膨満正常呼吸マウスと して, 口呼吸マウスの場合と比較した。その結果, 図 1 と全く同様の結果を得たので, 腹部膨満による横隔膜の 圧迫等の影響はないものと考えられる。なお，乙れは， 一酸化化炭素, トルエン暴露の場合む同様であった。

次に鼻孔閉銧にともなう腹部膨満をひき沶こさないマ ウス（このようなマウスが手術をしたものの中に約 1 割 あった）に硫化水素を暴露した場合, 鼻呼吸マウスとの 間に図 1 のような差がみられなかった（図 2 )。乙の原 因については，現在検討中であるが，次のような可能性 が考えられる。つまり， 口呼吸マウスで，過剩な空気與 下をおこさないマウスは，空気畾下をおこすマウスに比 べて鼻呼吸マウスに近い状態であろうという可能性であ る。何故なら，過剩な空気燕下をひきおこす口呼吸マウ スの食道を胃の入口で結紮し, 空気嬩下ができない状態 にしてやると $1 \sim 2$ 時間で窒息死してしまった。従っ て, 空気嶼下がおこるというととは, 口乎吸状態を示す 一つの指標とも考えられる。

なお， 口呼吸状態に変えてもマウスのように著明な空 気嚥下をひき抢てさないラット（幼若ラット，体重50〜 $60 \mathrm{~g}, \mathrm{~W}$ istar系令) で同じ実験（硫化水素, 一酸化炭素, トルエン蒸気暴露）をした所，マウスの場合と同様の結 果が得られた。従って, 空気與葆下現象の有無は有毒ガス による毒性発揮の差異とに直接関係ないとは考えられる。

4) 鼻孔閉銷一気管呼吸マウスにおける硫化水素暴露 の影響について

次に, この毒性発揮の差異が呼吸機能の障害に起因し ているのか, 鼻腔内神経系, 特に嗅覚に関係しているの 


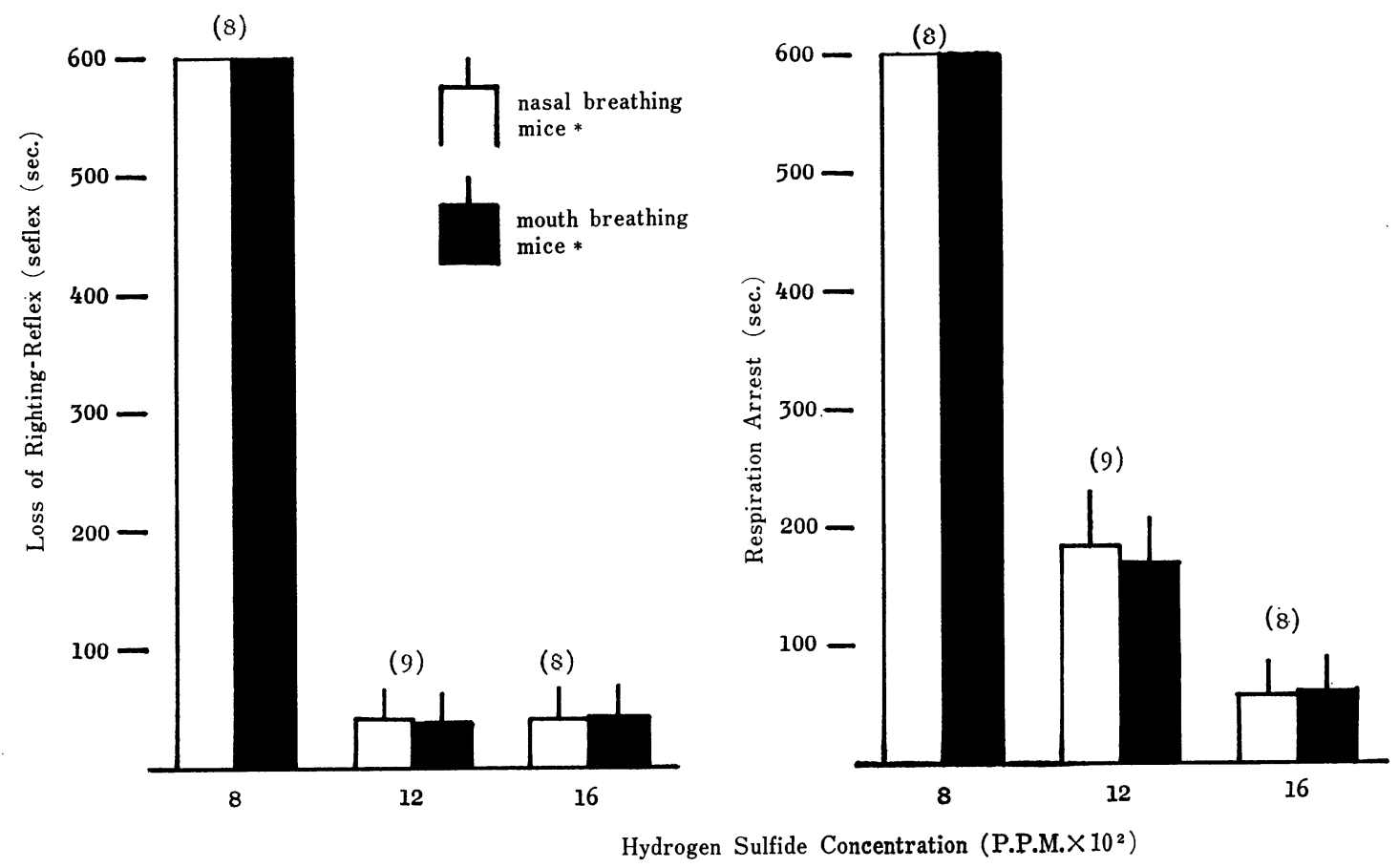

Fig 2. Time untill the loss of righting reflex (left) and the respiration arrest (right) under exposure to hydrogen sulfide.

* mice without aerophagy

(10)

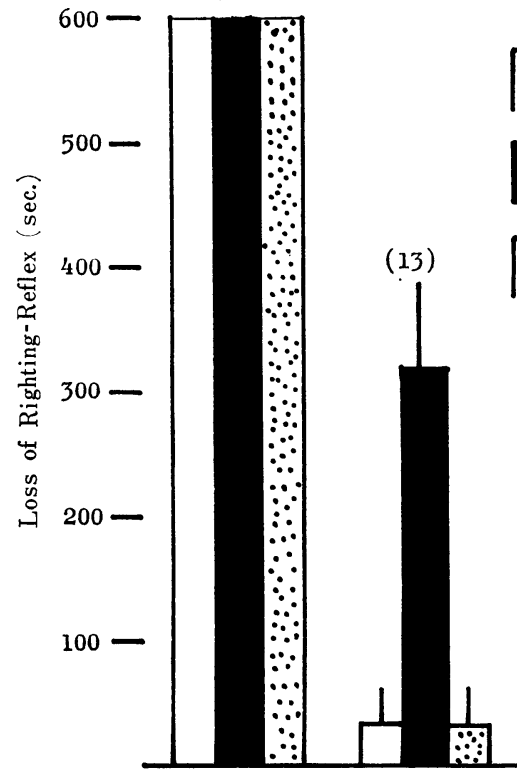

8

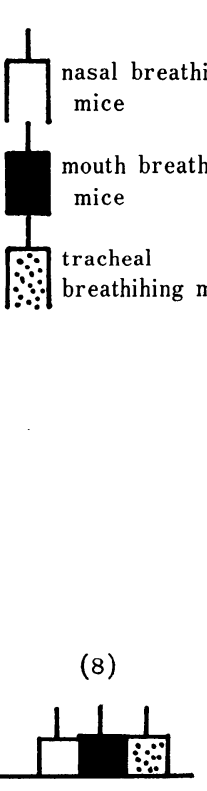

16
(10)

(13)

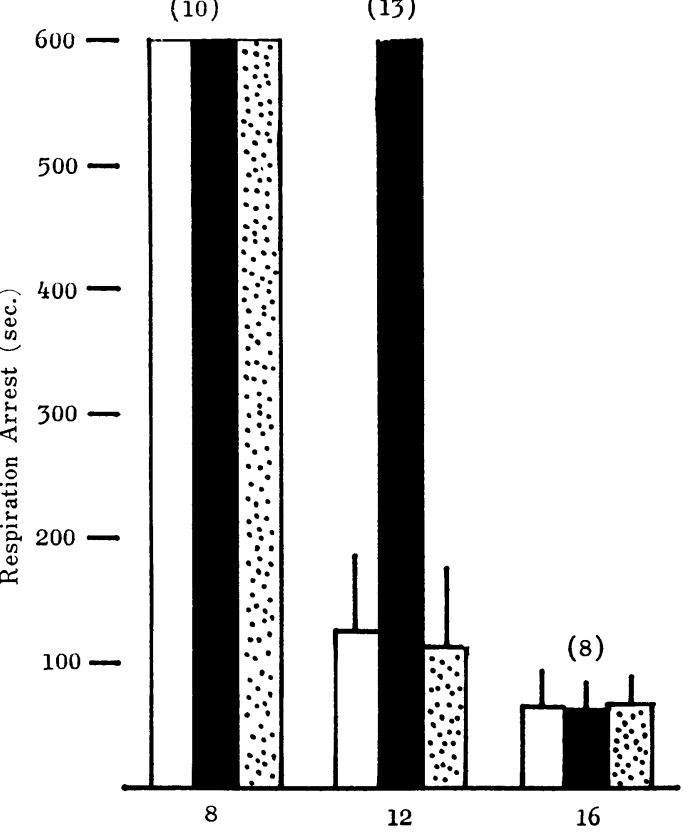

Hydrogen Sulfide Concentration (P.P.M $\times 10^{2}$ )

Fig. 3. Time untill the loss of righting reffex (left) and the respiration arrest (right) under exposure to hydrogen sulfide. 
かを検討するため, マウスの頸部に気管㾇を設け，鼻孔 閉鎖一気管呼吸マウスを作成した。このマウスは過剩な 空気嚥下をひきおこさないだけでなく，呼吸機能も鼻呼 吸マウスとかわらなかった [3]。乙の鼻孔閉銷一気管呼 吸マウスを, 鼻呼吸マウス, 口呼吸マウスと一緒に硫化 水素に暴露すると，とのマウスは，鼻呼吸マウスと同じ 傾向を示し，1,200ppm で口呼吸マウスのみが著明な差 を示した(図 3 )。このととから，口呼吸状態と鼻呼吸状 態の間でみられた硫化水素による毒性の差異は, 気管呼 吸により除去されるととが示された。これは，口呼吸の 際の呼吸障害が, 気管呼吸により回復したととと一致す るむのと考えられる。

また，口呼吸マウス，鼻孔閉鎖一気管呼吸マウスにお ける，ともに硫化水素が鼻腔内を通過していないにあか かわらず, 運動能力消失時間に差が認められた。従っ て, 鼻腔内神経系 (特に嗅覚) が, 有毒ガス暴露の際の 運動能力消失に関与している可能性は少ないと考えられ る。

さらに，亜硫酸ガス等の大気污染物質が，気管より上 部の器官 (主として鼻腔内) で, かなりの量が吸着, 吸 収される[11，32]ことが知られているが，肺への侵入率 の高い化合物の場合や, 高濃度有毒ガス暴露の場合は, 鼻腔腔内付着量は，ほとんど問題にならない可能性が， 鼻孔閉銷一気管呼吸マウスによる実験により示された。

人間の場合, 気管呼吸は, 正常の呼吸之, 呼吸機能の 面に怙ける，ほとんど違いがない[25]。乙の鼻孔閉鎖一 気管呼吸マウスの場合あ同様であろうと考えられる。従 って, 両呼吸様式マウスの硫化水素による毒性発揮の違 いは, 鼻閉塞による呼吸障害 (呼吸量, 換気能その他) 之，密接な関係があるあのと考えられる。

5 ）一酸化炭素に鼻呼吸ならびに口呼吸マウスを暴露 した合場の毒性について

マウスを一酸化炭素に暴露した場合7,000ppm 以上に なると数分で運動能力消失がみられた。一酸化炭素は, 火災等の際の毒性発揮の主因と考元られている。血中の $\mathrm{CO}$-ヘモグロビン濃度と, 運動能力消失時間に相関関係 が認められている[5,14]ので，ガス吸入量が少なけれ ば，それだけ運動能力消失時間が長いわけである。そこ で, 硫化水素暴露の場合と同じ実験をした所, 口呼吸、 ウスの方が，9,000 11,000ppm の濃度で，運動能力消 失時間が著明に長かった（図4）（しかし，呼吸停止に ついてはほほとんど差が認められなかった)。

6) トルエン蒝気に鼻呼吸マウスならびに口呼吸マウ スを暴露した場合の毒性について

トルエンは, シンナー遊び等に使用される有機溶剤の 毒性発揮の主因と考えられている。典型的なシンナー遊 びの方法は, シンナーや接着剤の適当量をビニール袋に

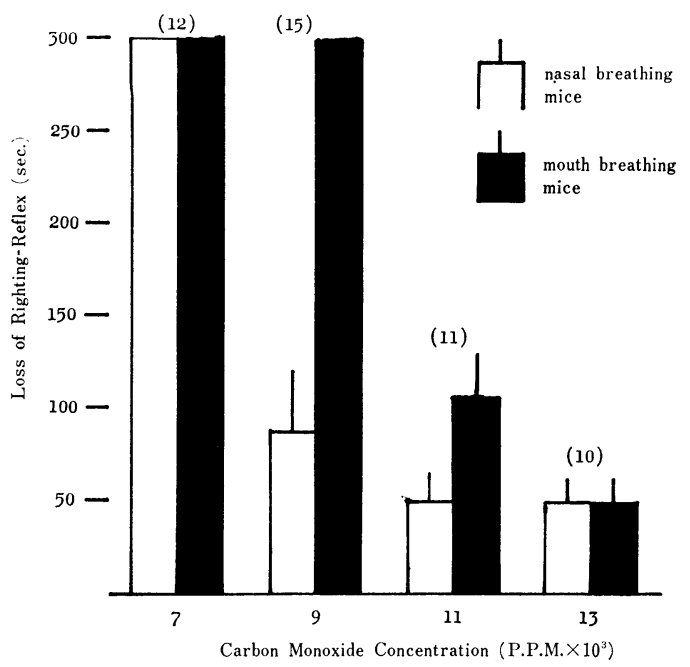

Fig. 4. Time untill the loss of righting reflex under exposure to carbon monoxide.

入れ，それを手掌であたためながら揮発した有機溶剤を 必ず口腔を介して経気道的に吸入する[39]という。そて で, 硫化水素, 一酸化炭素の場合上同様に, 鼻呼吸マウ スと口呼吸マウスにおいて, トルエン蒸気暴露の際の毒 性を検討してみた。その結果, 四 5 亿示したように, 鼻 呼吸ならびに口呼吸の急性毒性の発現が, 硫化水素, 一 酸化炭素の場合之全く同様の傾向で認められた。呼吸停 止時間については, 30分以上の観察が必要のため, 容器 内トルエン蒸気濃度が変化してしまう可能性があるの で, 観察不能とした。6, 000ppmトルエン蒸気濃度では, 30分以内の運動能力消失時間は, ともに認められなかっ たが，乙の場合，鼻呼吸マウスはかなり弱って運動能力 消失寸前であったが，口呼吸マウスは，明らかにそれよ り正常状態に近い状態であった。9,000〜15,000ppm の

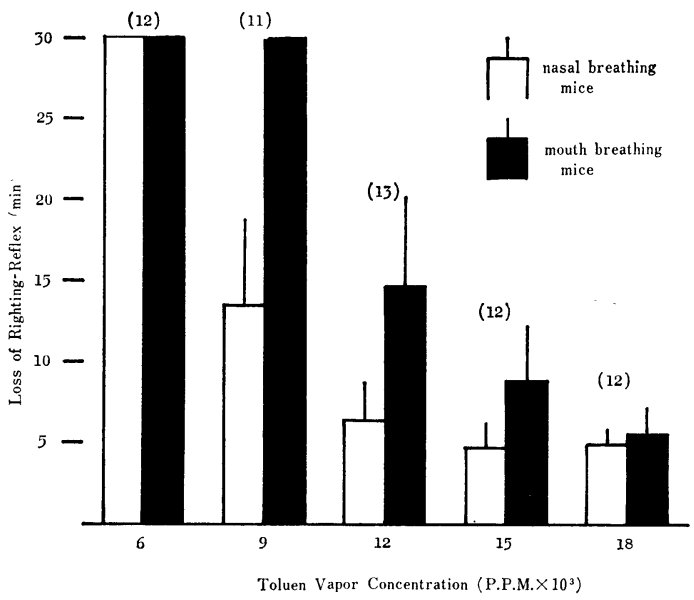

Fig. 5. Time untill the loss of righting reflex under exposure to toluen vapor. 


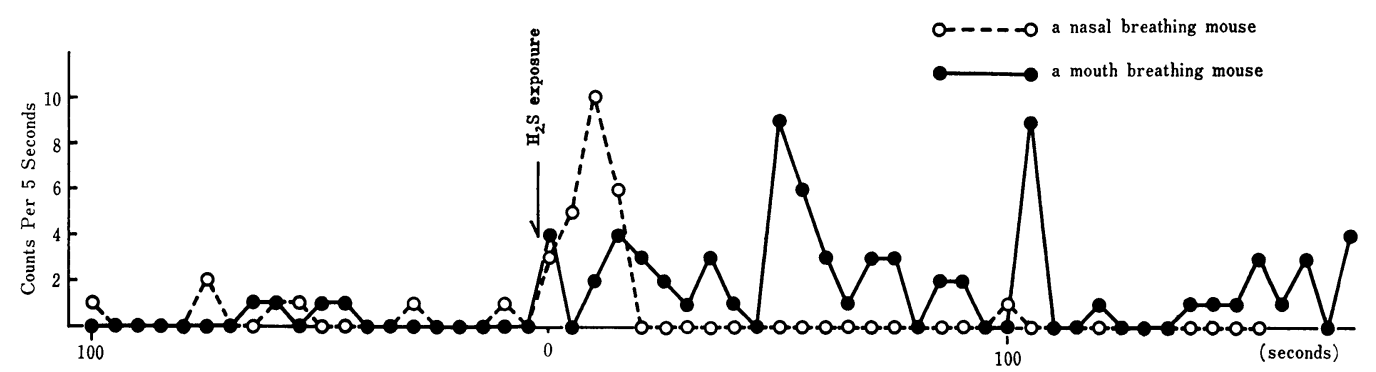

Fig. 6. Typical behavior of nasal and mouth breathing mice under exposure to hydrogen sulfide (1.200ppm)

範囲では，口呼吸マウスが鼻呼吸マウスに比べて，著明 に運動能力消失時間が長いことが示された。なお，それ 以上の高濃度の場合に抒いては差がみとめられなかっ た。

7 ）鼻呼吸マウスと口呼吸マウスの有毒ガス暴露時の 行動量の違いについて。

有毒ガス暴露時のマウスの行動量の多少については, 次の二つの要因が考えられる。一つは, 鼻腔内刺激に之 あなう苦痛によるあのと, 他は, 血流中に入った有毒ガ スによるあのとが考えられる。従って, 口呼吸マウスの ように, 鼻腔内刺激を少なくした状態で, 有毒ガスを吸 入した場合, 鼻呼吸マウスに比べてどうであるかを比較 したのが図6である。乙の実験では, 前述の二つの要因 を分離してみることはできないが，1,200ppm 硫化水素 濃度の場合, 最初の 30 秒間に, 両マウスの行動量に著明 な差がみとめられた。しかし，1,400ppm 以上の場合， 両マウスにおいて共に激しい動きが見られ，差はなかっ た。このととからあ, 鼻呼吸マウスと口呼吸マウスの有 毒ガス暴露の際の違いが認められた。

なお，鼻孔閉鎖気管呼吸マウスの場合，1,200ppm 硫 化水素に暴露されてあ, 激しい動きなしに, そのまま運 動能力消失がみられるあのが多かった。このととから， 有毒ガス暴露の際の鼻腔内刺激の有無が，マウスの行動 量と何らかの関係があるのではないかと考えられる。

\section{考察}

有毒ガス暴露による急性中毒, 中毒死は, 非常に短時 間のうちにおこり，防毒マスクを身につける時間的余裕 がないととが多い。これらは，ほとんど事故という形で 突発的に発生し，それに対処するすへはは少ない。そこ で, 今回は, 有毒ガスによる被害を少しでも軽減させる 方法をみいだすために，マウスを用いて，鼻閉塞による 呼吸抑制と有毒ガス暴露の際の毒性発揮の関係について 検討した。

鼻閉塞により，呼吸が障害されるというととは，人間
を中心に古くから知られている $[15,16]$ 。慢性的に鼻閉 塞をおこした患者と, 健康人で鼻に疾病を持たない人が 鼻をおさえた急性鼻閉と二通りあるが，いずれの場合あ 呼吸障害が認められている。現在までに知られている呼 吸障害は要約すると次のとおりである。(1)呼吸数が減少 し, 呼吸が浅く表面的になる。(2)胸部, 横隔膜の運動が 減少する。(3)鼻閉者は, 運動により早く自覚的疲労症状 をきたす。(4)肺活量が減少し，止息状態の時間が短縮さ れる。(5)肺コンプライアンスが減少し, 肺粘性抵抗が増 加する。以上のことから, 鼻閉塞により呼吸量, 換気能 が低下していることが考えられる。その他, 家兔 [24], 犬[36]等による実験的鼻閉塞と呼吸障害が報告されてい る。この呼吸障害と鼻閉塞の相互関係について, Sercer は, 鼻肺反射経路の阻害による[21]と説明している。つ まり, 鼻腔粘膜と胸壁の呼吸筋および気管支筋の間に反 射経路があり，呼気，吸気による鼻腔粘膜刺激によっ て, この経路が作動すると考えられている。従って, 鼻 閉により，この反射経路が充分使用されないため, 呼吸 障害がおこると考えられ，乙の鼻肺反射は，動物実験に よっても証明されている $[34]$ 。

そとで，前記のような呼吸障害を，マウスを用いて実 験的におこさせ, その状態で有毒ガスを暴露し, 毒性の 変化を検討したわけである。マウスの口呼吸状態の場 合, 過剰な空気燕下をひきおこす。乙れは人間の場合と 大きく異なる点であるが，ラットを用いた実験により空 気䗨下現象の有無は有毒ガスによる毒性発揮の差異とは 無関係であるととが示された。従って, 鼻閉により呼吸 が抑制された状態であることに関しては両者とあ共通で あろうと考えられる $[3]$ 。本実験では，毒性評価の指標 として，運動能力消失時間を用いたが，乙れは有毒ガス 暴露の際の生死をわける, 重要な分岐点として, 特に意 味があると考えられる $[10,37]$ 。呼吸マウスが，呼吸

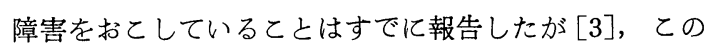
マウスを硫化水素, 一酸化炭素, トルエン蒸気に暴露し たとき，それぞれの有毒ガスの致死濃度付近で生死にか かわる急性中毒濃度において, 運動能力消失時間が著明 
に長くなるととが示された。との原因としては，呼吸を 抑制するととにより, 同一濃度の有毒ガスに 暴 露して あ，正常呼吸にくらべて有毒ガスの体内とりこみ量が減 少していることによるのではないかと考えられる。

そこで，吸入ガス量と毒性発揮の関係で，逆に，呼吸 が促進している状態ではどうであろうか。人間の場合， 運動時には，呼吸量が，平静時に比べて約10倍にもなる [9]といわれるが, マウスの場合も同様であろう。斎藤は， 火炎燃焼ガスの毒性という立場から，強制運動中のマウ スと, 静止状態のマウスを, 同時に, 様々な燃焼生成物 に暴露させ，運動不能に至るまでの時間を指標に，毒性 を比較しているが，静止状態のマウスの方が，運動能力 消失時間が長いと報告している[39]。また，人間の場合 でむ，いわゆる光化学スモッグによる被害は，ほとんど 運動中の学童において認められている[33]。従って，呼 吸量が増加すれば, 一定時間内の有毒ガスの体内吸入量 が増し，それだけ早く毒性があらわれるととを意味する と考えられる。

以上のことから，呼吸が促進している状態では，有毒 ガスに対して，より危険な状態になり，呼吸が抑制され た状態では，危険が多少緩和されると考えられる。従っ て，鼻閉による呼吸障害を積極的に利用するととにより 有毒ガス被爆の際，身を守る一つの方法となる可能性が 考えられる。なお，人間の場合，口呼吸は，鼻呼吸より あ容易に，随意に呼吸を調節することができるので，鼻 呼吸の場合よりも，より効果的であろう。

\section{要 約}

有毒ガス暴露の際，それによる毒性の発揮を軽減させ る方法の一つとして，急性鼻閉による呼吸抑制の影響に ついて検討した。前報で，呼吸が抑制されているととを 確認した口呼吸マウスを, 鼻呼吸マウス（正常呼吸マウ ス）を対照として硫化水素，一酸化炭素，トルエン蒸気 に暴露した。その結果，急性中毒をひきおこす濃度にお いて，口呼吸マウスの方がこれらの有毒ガスによる運動 能力消失時間が著明に長いととが明らかとなった。

以上の事から，鼻を閉じて口呼吸をすることにより， 有毒ガスによる毒性の発揮を軽減しうる可能性が考えら れる。

\section{謝辞}

終りにのぞみ，御校閲と有益なる助言をいただいた，群馬 大学医学部行動分析部門, 田所作太郎教授, 同第二生理学教 室, 元木沢文昭助教授, 同耳鼻咽喉科教室, 武藤二郎助教授, 同公衆衛生学教室, 永田稔講師, 東京都立衛生研究所大井玄
博士ならびに群馬県衛生研究所, 福島一郎所長, 賢治生物部 長に心からの謝意を表する。

\section{文献}

［1］中島克行, 滰島常雄(1972)。草津殺生河原噴出ガ スのマウスに対する毒性について(予報)，群馬県 衛生研究所, 公害研究センター年報, 4, 91- 92 。

［2］樋口洋一郎, 中島克行, 高橋勇夫, 斎藤譲, 滝島 常雄, 原田賢治, 狩野和男, 福島一郎(1973)。火 山ガスの急性中毒学的研究, 群馬県衛生研究所, 公害研究センター年報，5，175-182。

［3］中島克行, 土屋哲, 中嶋隆, 原田賢治(1974)。鼻 孔閉鎖による口呼吸マウスについて，実験動物， $23,225-227$ 。

［4］多田治(1972)。有害物管理のための測定法, 労働 科学研究所, p. 66 .

［5］古田昭一, 高木忠信, 吳大順, 佐藤憲蔵(1960)。 急性 $\mathrm{CO}$ 中毒と高圧酸素療法，医学のあゆみ，58 (別冊), 246-260

［6 ］勝沼精蔵, 斎藤十六, 高橋忠雄, 笹本浩(1967)。 内科学(中巻), 医学書院, p. 979.

[7] W.B. キャノン（舘鄰，舘澄江訳）（1967）。から だの知恵，平凡社， 456--465

［8］平賀士郎，鈴木賢雄(1973)。神奈川県温泉研究所 報告， 4，47-53.

［9］久松栄一郎，猪飼道夫(1964)。スポーッ医学，体 育の科学社, 163

［10］田所作太郎(1973)。火山性硫化水素の毒性をめぐ って, 化学々生物, 11, 735-742.

[11］横山栄二(1960)。 $\mathrm{SO}_{2}, \mathrm{O}_{3}$ 抢よび $\mathrm{NO}_{2}$ 暴露時の 呼吸機能，医学のあゆみ，58(別冊)，78-89・

［12］高橋建吉, 旬坂馨(1966)。急性硫化水素中毒, 法 医学の実際と研究, 10, 26-35.

[13] T.H. Milby (1963). Hydrogen sulfideintoxication. Review of the literature and report of usual accident resulting in two cases of nonfatal poisoning, J. Occup. Med., 4, 63-64.

［14］Ｆ.W．サンダーマン（池田良雄監訳）（1973）。新 しい毒性学, 広川書店, 236 .

[15] Hofbauer (1912). Pflügers Archiv für Physiologie Band 147, S. 271.

[16] Henrici(1918). Zeitschrift für Ohrenheilkunde Band 77, S. 31.

［17］湯浅浩一(1938)。鼻呼吸障碍に関する呼吸生理学 的研究，大日耳鼻， $44 ， 833$.

［18］湯浅浩一(1939］。完全鼻閉を伴う鼻茸症例の呼吸 
運動に就て，満州医誌，30，153-165.

[19] 湯浅浩一(1939)。防毒マスクの呼吸生理学的研究 並に之に適応する呼吸方式の批判, 満州医誌, 30, $137-152$.

[20］湯浅浩一(1939)。実験的鼻閉の胃液分泌に及ぼす 影響, 満州医誌, 30, 601-615.

[21] Sercer, A. (1941). Zentralblatt für Hals, Naseu Ohrenheilkund Band 34, S. 411.

[22]平田松太郎(1942)。鼻閉之肺活量, 日耳鼻, 48 , $974-978$.

[23］白岩俊雄, 渡部三郎(1953)。鼻閉塞に関する臨床 的研究, 耳喉, 25, 592-597.

[24］古沢慎(1960)。鼻呼吸障碍の生体に及ぼす影響に ついて, 北海道医誌, 35, 117-141.

[25] 江口実美, 福崎隆(1966)。気管呼吸患者（愛喉剔 者）の呼吸機能検査成績について, 日耳鼻, 69, $48-52$.

[26] Ogura J. H., J. R. Nelson., R. Dammkoehler, M. Kawasaki and K. Togawa (1964). Experimental observations of the relationship between upper airway obstruction and pulmonary function, Ann. Otol. Rhinol. Laryng. 73. 381 -403 .

[27] Togawa, K., and Ogura, J.H. (1966). Physiologic relationship between nasal breathings and pulmonary function, Laryngoscope 76. 30 -63 .

[28] Ogura, J.H., Togawa, K., Dammkoehler, R., Nelson, J.R., and Kawasaki, M. (1966) Nasal obstruction and the mechanics of breathing.
Arch. Otolaryngol. 83. 135-150.

[29] Ogura, J. H., Unno, T. and Nelson, J. R. (1968). Baseline values in pulmonary mechanics for physiological surgery of the nose (preliminary report). 77. 367-397.

[30] Unno, T., Nelson, J. R. and Ogura, J. H. (1968). The effect of nasal obstruction on pulmonary, airway aud tissue resistance. Laryngoscope $78,1119-1139$.

[31］海野徳二, 武宮三三, 戸川清, 今野昭義, 嶋田文 之(1971)。鼻疾患と呼吸機能との関連について, 耳鼻臨床, 64, 1177-1182.

[32] 横山栄二 (1972)。 $\mathrm{O}_{3}$ の肺機能におよぼす影響, 光化学反応による大気污染, 日本公衆衛生協会, $123-143$.

[33］外山敏夫(1972)。オキシダントの人体影響に関す る研究, 環境保健レポート，13，61-67.

[34] 奥田典(1958)。鼻呼吸障害の労働能力に及ぼす影 響について，日耳鼻，61，901-918.

[35] 渡部三郎(1956)。鼻閉塞の呼吸運動におよぼす影 響, 日耳鼻, 59, 513-521.

[36] Skachow, A. A. (1931). Monatschrift für Laryngo-Rhinologie $65 \mathrm{Jahr}, \mathrm{S} .118$.

[37］斎藤文春, 吉田正志 (1972)。燃焼生成物の毒性 (III)，建築研究所年報，149-157.

[38］土屋哲, 中島克行, 中嶋隆, 原田賢治(1974)。有 毒ガス暴露動物実験用簡易装置について, 群馬県 衛生研究所, 公害研究センター年報, 6 , 投稿中。

[39］田所作太郎(1974)。シンナー遊びの行動中毒学, 医学のあゆみ, 88, 300-304. 